\title{
Memories of Breathing: \\ A Phenomenological Dialogue: \\ Asthma as a Way of Becoming
}

\author{
Monica Clarke \\ University of Victoria
}

Bronchial asthma is a common disease characterized by spasmodic attacks of wheezing and shortness of breath. (Cole, 1971, p. 113)

We were bound on the wheel of an endless conversation.

Inside this shell, a tide waiting for someone to enter.

A monologue waiting for you to interrupt it.

A man wading into the surf. The dialogue of the rock with the breaker.

The wave changed instantly by the rock; the rock changed by the wave returning over and over.

The dialogue that lasts all night or a whole lifetime.

A conversation of sounds melting constantly into rhythms.

A shell waiting for you to listen.

A tide that ebbs and flows against a deserted continent.

A cycle whose rhythm begins to change the meanings of words.

(Rich, 1971, p. 53)

In the fall of 1988 my 15-year-old daughter won the Munro book prize for an essay that she called "Memories of Breathing." I remember our exchange as she cast around in frustration searching for a topic that could be special. I offered my usual array of maternal teacher-type advice. Write about something you know well, a happening, a feeling that is yours. And so she did, and afterward I will speak to this.

There are other voices embedded in our dialogue, those written in italics. They are the voices of poets, as illustrators and whisperers, destined to give what Merleau-Ponty (1962, p. 179) calls a "gestural meaning," which lives in the emotional content of the word, and fill the frame of Heidegger's (1971, p. 140) description as "the sayers who more sayingly say." 


\section{Memories of Breathing}

Sasha's Story

Most people don't think about breathing. They breathe 20 times a minute; they breathe faster or slower; they take great gulps of morning air; but still, they don't think about breathing.

I remember sitting in the waiting rooms of hospitals over the years with my mother when I was between seven and 11 years old and trying desperately not to stare at the other people sitting, waiting. I would watch them waiting, wondering what on earth they were doing there. They just sat and waited.

Some of them never looked the least bit sick to me, but maybe I always imagine sick as dying, or maybe it was because they looked like ordinary people you might see in a parking lot or the supermarket. They wore ordinary clothes, but one thing was that most of them seemed to have all these three-to-five-yearolds who would jump all over the chairs and make too much noise so that their parents were always asking them to sit down or shut up. I always wished that they would too because they reminded me that I could hardly walk.

I can't decide what I hated more, the waiting or the idea that everyone was watching me be sick, not throw-up sick. Just sitting there fighting for air and the pain of the ache in my chest. Sometimes I would get so scared I was gonna die. I sometimes even used to make my will out sitting there, waiting, and wondered if anyone would miss me. I always thought my Mum would cry and my sister would get all my stuff, but I decided that I would tell my Mum (if things looked really bad) that my sister was under no circumstances allowed to have my things and that would she please give them to Laurie Lunden, my best friend.

We used to wait for such a long time. I can remember. Sometimes it gets a little hazy and things always come in the wrong order, but I still remember. I always felt like I was running out of time for some reason. I think maybe it was that I thought I couldn't last a second longer. It was as though my chest was going to cave in on me and I just wasn't going to be able to take enough breaths so that I would last until they could fix me.

I always told my Mum that this was the worst one ever but she always said that it was just the same as last time. I never believed her. I used to think she wouldn't say that if she could crawl inside my body right now, but I learned later that she was right. I think it was just because I was so scared. Sometimes I used to cry and that only made it worse, so I stopped. I remem- 
ber when we were checking in, it always reminded me of checking into a hotel, but for sick people I guess.

The only thing that made it sometimes okay was that I got to ride in a wheelchair. I loved that. I would try and get people to wheel me all over the place. If I got admitted I would ride up and down the hallway outside my room as fast as I could dragging my IV with me.

Once I met another girl, older than me. She was there because she had been hit by a car. I remember she had a broken leg and a black eye and I was really sad because she had the prettiest long brown hair. I thought it was so sad because she was so pretty and people with hair like that, well ... things like that just shouldn't happen to them. My Mum brought me a game of checkers one time and we played so many games of it. Thinking back, I think my Mother must have been going bananas by the time I left.

I didn't always check in though. It would get better and they said I could go home, but sometimes I wanted to stay just in case I got sick again. Lots of times I just went into Emergency and sat on a bed that always reminded me of my bed because it was so springy. They used to make me get changed into one of those nighties with only ties in the back. They were always a grey color that reminded me of a misty, rainy morning. I used to get so embarrassed, because I thought people could see. The doctor would come in and listen to me breathe. What he heard I don't know. I used to get less scared by this time because I knew I was gonna get better. I would lay back on this springy bed and they put an oxygen mask over my face. I always found this incredibly farcical when I lay down and my nose started to run. I couldn't imagine why I had been so scared. It was also that my Mum used to start saying breathe in, breathe out whenever I sniffed. I can remember how cold the railings on the bed used to feel, just like popsicles in summer.

Now looking back and trying to find a way to make myself more descriptive, I find I can't change a word because to me the words are trapped in the time and to change the words is to change the time. Some people say they hate hospitals but I could never understand why because to me it was the place I went to get fixed. It was safe. They can make me breathe again.

So Sasha tells her story of what she knows well, a happening, a feeling that is hers. I am there in her story but it seems that I really lived mostly in the preface. 
I hold her in my arms again, another night, like other nights. It is two o'clock in the morning. She is five years old and I am ageless, ancient with fatigue.

Throughout the day I have watched and listened, feeling the gradual escalation of the asthma attack. This path is well known to us. A few nights ago saw the beginnings of a small cough that joined and smudged with the night sounds. The days were fine, almost surface normal, except for the wheezing noises after the somersaults on the carpet, or the bubbly cough that was with her in the warm steamy bathroom.

I knew our steps were quickening when I saw her shoulders held tight and high and her nostrils flare on inspiration. Despite this I made no plans, no preparation for contingencies, no decisions. I kept thinking about the side effects of the course of steroids only just finished again, and I could see that the theophylline for her breathing was making her restless, irritable, and anorexic.

Her pulse is very fast from the side effects. She is so small.

I was asleep when I heard the asthma find a new tempo of assault. Closed doors, but I knew and I was up, the dark house sliding past me. She sits Buddhawise in the middle of her bed, hands on knees, shoulders high and wide, mouthing speechless words. I help her with the inhaler and there is some relief for the words come-"Mummy, Mummy"-a small breathless chant.

I pick her up, her arms around my neck. She grips but holds herself away, straining upward and leaning back with the need to have space all around her chest. We go into the kitchen, all blue shadows in the night light. I put her on a high stool, her arms up on a pillow on the kitchen counter. We try the inhaler again. This is wrong, I know. She has already had too much and it is not working.

Dark curls matted stuck to her forehead, all of her sweaty under my hands. Little shoulders, ribs. Her lips are dark blackish in the dim kitchen light. I have to decide what to do, but I am empty and stupid. My thoughts fly high above the moment, not touching us, not present. I am outside myself watching the scene that unfolds like a bad movie.

We wait in the darkened kitchen for nothing. Time is gone. There are only the two of us in this other world where moments are measured by the flailing labored breathing.

She starts a barking cough so demanding that there is no space for breaths. Her eyes fill to cry and I am there living in my anger and my fear. "Stop that, don't cry, just breathe damn you, 
breathe." I have my car keys, a coat, a blanket. I throw words to the others in the sleeping house. "We are going to the hospital."

"I remember," said Sasha "I was shouting so loud mummy, mummy, mummy, but I knew it wasn't loud enough. I knew you couldn't hear me."

"I remember," Sasha said, "you always seemed pissed off at me when my asthma started. It just always made you mad. I would ignore it for as long as I could and then suddenly it was always too late. I knew it was a real hassle for you and messed everything up, but it was a hassle for me too because I couldn't do it without you. If I forgot my Ventolin you would get so mad, even if we had not made it out of the driveway you would be beserk. I had to ask you to go back though because I had to have it. Now I never forget it, it is just a part of my stuff. Alex my friend used to say to me, 'Sasha, have you got your Ventolin?' and I would say to him, 'Hey, what is this, are you my mother or something?"”

$* * *$

My voice goes after what my eyes cannot reach,

With the twirl of my tongue I encompass worlds and volumes of worlds. (Whitman, 1891-1892, p. 47)

Two minutes from the house hears my unconscious litany of daily checks. "Have you got your Ventolin?" The small voice is defenseless, and the flattened tone is my answer. It is only a forgetting: an accident that begets a twisted pileup of tangled emotion. My anger collides with my body and slams me back against the car seat and my driverless tongue becomes a whiplash of frustration. I am a scourge.

Anger. Anger. It spreads like orgasmic heat through my belly and my chest. White fists on the wheel. Ugly hands that match the wild harridan.

My throat is thick with some unnamed feeling and my breathing as ragged as hers will be later when the asthma comes and the Ventolin is not there.

We turn around and go back to the house.

And our two souls so left

Achieve no unity:

We are each one bereft

And weeping inwardly. (Livesay, 1986, p. 79) 
Do you remember Sasha, when you learned to use the inhaler? You were really small when I taught you. Once, we went to see the allergist and after the tests he asked to watch you so that he could assess if you did it correctly. He said he had never seen a small child use an inhaler so effectively. But I already knew because I had taught you. Do you remember? You would sit in the curve of my lap like a spoon, upright, chest to chest, with my face next to your face over your shoulder. And my lungs next to yours felt the bellows hiss and my chest burned from the weight of weightless air.

I would shake the inhaler and then you would shake it. Now, "Ready, blow right out as far as you can blow, blow and then blow some more. Now ... PUFF ... PUFF ... the Ventolin into your mouth, all hands together, and slowly ... slowly ... pull the air in through your teeth and over your tongue and then deeper ... and deeper ... NOW HOLD IT, HOLD IT! start to count. Oh, so good, you are so good" ... big bug eyes rolling around. "Pretty funny eh!" and all the extra air wanting to come out pushing out your cheeks like a trombone player, pretty funny, mine too, "Look Look!"

"Oh, yes, my mother, I remember that! It was always such fun. I would try and count and see if I could get to 20 . Sometimes I could only get to eight or 10 but the second time I could get to 14 usually."

$* * *$

"When I take my Ventolin now, I can pull everything that is me into this little tiny space. My vision gets unfocused and goes completely black. Then when I let go, I go back out again."

to kneel; and hold with choking breath one's own

contracted contours, trying to expand,

tight in one's heart like horses in one's hand. (Rilke, 1964, p. 34)

\section{***}

"I remember," Sasha said, "I remember when I first started hiding my asthma. It was in grade 8 and there were boys and we would always be fooling around. Well, I would palm my inhaler and then shake it under my arm ... like this.... Then I would kind of twirl around and then when I was facing the other way I would have a puff and hold my breath in my twirl and then they didn't notice. That is the worst thing. How people notice. Some people ask lots of questions and then I have to answer even if I don't want to; some people just look at the inhaler and then just 
look away quickly. But whatever they do, they always notice. The guys seem more accepting than the girls. Except for Becky-it always frightens other people, but I'm glad it frightens them, it has frightened me for years. I want it to matter to them and to be important so that I don't seem to be neurotic, because a lot of people think that asthma is nothing. I don't resent them because I have asthma but I can never be perfect and sometimes I feel like I am physically handicapped or something. I want to start where everyone else started. I want to be on equal terms."

If there are guardians around you

they do not reveal

how ably you'll take hold of pain

and shake it off

and twist the corkscrew in your heart

and turn and laugh again. (Livesay, 1986, p. 47)

Oh my Sasha, I remember when you went to high school. So anonymous. You with your A's. A for French, English, and Math. A for asthma. The PE teacher was a big blonde woman with affronting muscles. So aggressively living what she was, that she wore her fitness like a uniform, never knowing how her great shoulders and gesticulations intimidated us. And in her goal oriented grade-dom she assigned you meaningless reports and the dust laden duty of putting away the mats.

I had to get you a medical release from Phys Ed, knowing as I did so that you would no longer value your small athletic achievements like riding your bike to school. The signatures on that piece of paper were reminiscent of the era when the frail and failing adolescent schoolchild had feathers burned under his nose.

and to divine the whelming desolation, the inexorable impersonality, of all that childhood needed to withstand:

And even then depart, hand out of hand, as though you tore a wound that had been healing, and to depart: whither? (Rilke, 1964, p. 30)

"I remember," Sasha said, "It was only a few months ago. You guys were out. It was a Saturday night and you had gone to a barbecue at four. I felt it coming and I just started sitting in a chair because I would need Ventolin without doing anything. Then it just seemed to pick up momentum from there.

"I was watching TV but I don't know what was on. There was the digital clock on the VCR above the TV and I was watching 
that. I saw every minute go by like $8: 30$, then $8: 35$, and $8: 40$, and then it would be $9: 30$ and I would not know how the time came, I was just there. I was wishing that you would come home, I had decided to spend the night in the chair. There was no way that I could lie down. There was nothing I could decide to do till you came home. I knew that you would give me prednisone. I suppose I could have gone to the hospital or taken the prednisone myself. I knew how many pills and where it was. I sat up till you got home. I wasn't scared, it was all too familiar, I knew every stage. I was frustrated. I waited for you."

You gasp "Hi! It's bad," and your hands extend and smile. You can only speak in phrases that are guillotined. Your body lines mirror the planes of the chair: drafted mathematically. Your back and head upright and your forearms flat on the chair arms. Your eyes show gladness that I am here, as I would be glad if the plumber came for a recalcitrant drain. You are waiting for me and I am wine warm and soporific.

You are waiting for me and I did not think to leave a number.

You were waiting and the dead hours that were your breathless limbo are lost to you forever.

We are both calm. I give you a loading dose of prednisone, not liking to make medical type decisions, but knowing it is the only decision against the mad flutter of xanthines. I leave the bedroom doors open so that I can hear if you are in trouble. But I know that you will manage now till morning.

***

Sasha said, "It is good to talk about all this and stop pretending that it hasn't made any difference to me, that it hasn't made me what I am. Of course (joke, joke), you realize that I can never leave home because I couldn't afford to support my habit."

\section{The Fabric of Asthma}

Merleau-Ponty (1962) reminds us that communication between consciousnesses is not based on the common meaning of our respective experience, for it is equally the basis of that experience. Rich (1981) writes about our essential separateness and our urge to reach for one another when she says:

I can't know what you know

unless you tell me

there are gashes in our understandings

of this world 
For Sasha and me this is just a beginning. Our stories bring meaning into existence, essences that are for us not only embodied in the text but part of our Being, of our history. MerleauPonty (1962) writes that, "the end of the text will be the lifting of a spell. It is at this stage that thoughts on the speech or text will be able to arise" (p. 180). The stories we have written are the fabric of our Being in the world. We are, Sasha and I, the warp and weft of our own weaving. But before we laid the warp or cast across the weft, the essential fibers of our separateness were already spun by genetics, in the world, and with others to make us what we are.

\section{For the Child}

\section{Sasha: Et Spiritu}

The word air in the old French form of aire is related to a sense of place; it is also related to song as in aria; and again in eyrie as the wild hawk's high place in the air.

The verb "to breathe" is rooted in spirare; esprit; spiritus, collectively as inspiration; breathing; breath; air; life; soul; pride; courage. What is it like, then, for a child with asthma to have difficulty with all such essential elements, and does a difficulty with one transpose to a difficulty with all? Whitman (18911892) in The Body Electric paints the full dimension with words and if the body does not do fully as much as the soul? and if the body were not the soul, what is the soul? (p. 75)

Sasha describes "fighting for air," "so scared I was going to die." When her fear was with her we never spoke of death, and now I wonder what was her sense as a young child of body and soul. What would death have meant to her, and would the meaning be similar for any child? From where did she draw her courage?

\section{Asthma as Ambiguity}

A child with asthma must dwell in conflicting realities; after all, until events are out of hand there is no classic look of sickness. The episodic nature of asthma and the triggering mechanisms of everyday occurrences feed the constant doubt that any difficulty will be perceived "to be neurotic ... because a lot of people think that asthma is nothing." Heidegger (1977) speaks of "dwelling" as the manner in which mortals are on earth. How does a child, then, dwell in sickness and in wellness? There are rules and expectations for being "sick," and we learn quite early on how to behave in this role. One should be seen to take care of 
oneself, eat well, rest, be compliant and concerned. The asthmatic child is given a different set of rules known only to those experienced with asthma. Asthma isn't sickness, behave normally, do as much as you can. In other words, act well until you get sick, but don't act too well, such as pushing against your limits and making yourself sick. If the child dwells in the world of sickness he or she will be considered neurotic. If the child dwells in the world of health, then the existing rules and mores will soon find him or her "wimpy" and deficient in stamina.

\section{Limited Time}

Running out of air is experienced as "running out of time" that the child cannot "last a second longer." Is this because she is not in space or time as we measure it, but rather that the child belongs to space and time together? As her space recedes and closes and the capacity for air diminishes, time becomes measured by every gasping breath. Time becomes breathing. Breathing is time.

We constitute ourselves in the historical present. For a small child in the throes of a severe asthma attack, "every time is the worst one ever." Could it be as Merleau-Ponty (1962, p. 140) thinks, "that the body necessarily exists now; it can never become past; and we cannot retain in health the living memory of sickness" ... these "gaps in memory" merely express the temporal structure of our body? This is possible, or perhaps the experience of running out of air and time is the ultimate crisis and threat to self. The sudden acceleration of time as a diminishing resource gives an asthma attack a sense of immediacy and urgency. The experience of crisis must be experienced as crisis: a turning point in life.

\section{The Comfort of Tears}

Comfort is rooted in "confortare" to strengthen. To gain comfort is to be "with strength" but the release of tears as a way of regaining strength is rarely an option in an asthma attack. In any other situation the catharsis of tears is an allowable refuge; in asthma, it becomes a catch 22 . The throat-swollen thickness that crying brings is no panacea. "Don't cry, damn you. Breathe, don't cry." The cry of the parent shackles the child in emotional bondage. The fear of the parent that crying will only make things worse becomes evident to the child. As Sasha said, "the crying made it worse, so I stopped," but the burden of fear remained. 
The hospital can becomes a haven, a place of diversion, a place of safety. For a child in the throes of recurrent phases of asthma the hospital can begin to represent a place of liberation from fear. Often treatment routines follow a predictable pattern and as expectations are met, such as access to the nebulizer and the oxygen mask, fear starts to ebb away and be replaced by other feelings. The sense of liberation that Sasha describes is evocative of the paradoxical whimsy of Kundera (1984, p. 314) when he says, "happiness fills the space that sadness owned." Things can become "incredibly farcical" and the child cannot imagine "why I had been so scared." Yet when Sasha reflected to write her story she remembered all her fear collectively. Is this how fear is remembered over time? It seems that in the immediate situation when fear is relieved, experience of the crisis becomes more temporal. This was the time when Sasha remembered deciding who would get her belongings if "things looked really bad." In an arena of safety, of knowing that "I was gonna get better," fear gave way to play: "riding in the wheelchair" and pleasure: "I loved that."

\section{Asthma as Concealment}

A child who cannot breathe effectively at both predictable and unpredictable occasions quickly senses the disadvantages that a disability can bring. What is it like to feel that you can "never be on equal terms" in a world that cries equality for all; never to be "perfect" in a world that reifies perfection? What is it like to feel "physically handicapped" in a world of sleek athleticism?

Hiding asthma becomes a ritual, a personal behavior, a way of life, and like all hiding it eventually becomes a secret: a personal burden. What is it like for the child to share the experience of the man looking through the keyhole that Sartre (1966) wrote about. Should she abandon her asthmatic body and try to join the scene on the other side of the keyhole, then to be observed and feel shamed and defenseless? For the child asthma is often a hidden affliction trivialized before the world. And the abnegation does not end here. Real achievements are diminished. The child's grand efforts with their faint rewards are made to seem small and insignificant when judged by the harsh criteria of the healthy-lunged world. What is it like to keep trying in the face of this? Where is such a child's place in the curriculum for physical education? What does she come to know about the hidden curricular values?

Van den Berg (1972, p. 110) examines aspects of self-concealment in relations with others: one can hide, keep something 
secret, disguise. In her story Sasha did all of these at one time or another. The experience of the child when the hidden trappings of asthma are observed and noted are, as Sartre (1966) observed, that "his body clots under the other person's stare" (p. 112). Sasha is very aware that "it frightens people" and that "they always notice." It is on being discovered that the child experiences being seen as different and the aggregate of these experiences becomes a stigma, internalized and worn as a psychic tattoo.

\section{Silence as Absence}

Absence is by definition the nonexistence of essence. There was in Sasha's story a sense of isolation when she was calling for her mother or when she was waiting for a parent to come home. It seems for a child in distress that there is no innate certainty that the parent will immediately come to help, and they must wait the slow wait. In absence there was silence, and in silence, absence. For Sasha these were abstractions and her concrete, lived experience was wanting her mother to come and calling "Mummy, mummy, mummy," and "I was just wishing you would come." Compressed years of calling shifted this experience into an accepting patience: "I just waited." The parent remains essential to the experience.

\section{Waiting and Freedom}

For the child on the threshold of adulthood there is a sudden surge of independence that is frustrated and held back by the asthma. The child still needs the comfort of the parent to be "with strength." At bad times even when the child knows what action the parent will take to help, there is a reluctance to assume an autonomy. Self-administration of drugs is an unwanted responsibility for the adolescent to assume, and difficult for the parent to abrogate now that there is also the beginning realization of the drug costs involved. Within the warp and weft of the relationship, the dialogue of a thousand nights, the parent and child develop a kind of symbiosis with the asthma: the child says, "I was waiting (for you)"; the mother says, "you were waiting (for me)." With such ties still in place, it is as MerleauPonty (1962, p. 456) says, that "freedom flounders in the contradiction of commitment."

\section{Asthma as a Way of Being in the World}

Asthma can become the child's way of being in the world. It is the esprit, the spiritu. It is, as Sasha says, "what I have become," "What I am." In this statement she moves closer to Heidegger's concept of "understanding," so closely bound to 
unconcealment and disclosure. For Sasha, as for Whitman, if the asthmatic body is not the soul, what is the soul of Sasha?

\section{For the Mother}

\section{The Face of the Night}

Any particular night of being up with a sick child can disappear into the memory of a thousand other nights. It is "another night, like other nights" when as Rich (1971) says, there is

The dialogue of the rock with the breaker.

The wave changed instantly by the rock; the rock changed by the wave

returning over and over.

The dialogue that lasts all night or a whole lifetime. (p. 53)

The experience returns over and over. No one night is really the same as another, but the variations in events were minimal, leaving an essential theme of what it is for a parent to experience a child's night with asthma. Always the fatigue, the ageless ancient quality, the inexorable press of circadian rhythm which left my body cold and slow. There was a sameness to the nights. It is only on reflection that I can perceive how the small changes in existence altered the experience from the early years to recent nights.

The house is different at night. The sense of space, color, and sounds cause me to relate to it differently. The limits of the room slide away into shadows, moving the immediate space closer to my body. The light has a quality that only darkness can bring. The house sounds different. It is sensitive to my unusual presence, and echoes back my movements. It is the world of being-up-in-the-night-with-a-sick-child.

\section{The Sentience of Asthma}

The parent watches the escalation of the asthma in the child. She is the silent reader of the voice, the gestures, the movements; she is the interpreter of the language of asthma, the receiver of the gestalt.

The image of the sick child waiting for the parent becomes like an icon imprinted into visual memory. It is like a frame frozen in time, stripped of movement.

a tide waiting for someone to enter.

a monologue waiting for you to interrupt it. (Rich, 1971, p. 53)

There is a sense of suspension. In a way it is like watching the media coverage of some catastrophe to which our eyes and brain have become immured, but it is more subtle than that. The 
experience is intuitive and incremental. There is the same sonar essence that is present when the parent hears the child through the curtains of sleep. The parent can feel the asthma. The waiting is helpless and devoid of anticipation.

Waiting for the illness to recede is like waiting for nothing. Like a "tide that ebbs and flows against a deserted continent" (Rich, 1971, p. 53).

Normal breathing is an unconscious action. Asthma is a conscious struggle, it is something, so it is in polarity that waiting for normal breathing is waiting for nothing. There is a sense of disconnection, of "being outside," of "watching a scene unfold," of "being in another world."

\section{Anger as Anguish}

The parent feels powerless in the deep desire to help the child who suffers. The parent feels bodily the "weight of weightless air" and shares the "ragged breathing" even in anticipation of something that may not happen. There is an anger born of helplessness for the anonymity and the trivializations the child has to cope with.

Anger shares the roots of grief. Anger is rooted in angere which is anguish, anguisse is narrowness, agkhein to strangle.

There is a physical quality to the feeling of powerless anger. It is a collision, heat, and an unnamed thickness; I am anguished and I become anger. On reflection I feel my shame again, I see myself, "the wild harridan" in her defenseless tone of voice. I remember clearly the clenching stranglehold, the agkhein, the anger on my body. My experiences of anger have had many faces, but those angry responses for forgetting the Ventolin were significant in their predictability, almost a culmination. In part, I anticipated her helplessness if she became breathless and had nothing to help her. There was also a feeling of helplessness for myself, of responsibility, of weight, of a burden of trust. This could be, I think, the other side of freedom. The price of beingfor-the-other.

\section{Comfort and Ritual}

The response to a chronic illness like asthma becomes ritualized. There is relief and goodness in the ritual because they become rites of faith. Creating the rituals together gives parent and child a physical bond and a close tactile sensing of breathing. The rituals were akin at times to prayer or some form of meditation, and at other times there was a sense of "fun" and of togetherness. Rituals have a presence and an order, and I know that Sasha still counts and breathes in the same learned way. 
Relief is sought in the embrace as well as in the medicine. In this poem "On the beach at night" Whitman (1891-1892) writes

Weep not, child,

Weep not, my darling,

With these kises let me remove your tears (p. 189).

and in these lines we live the urge to give strength in an embrace, to make up for the denial of tears. Within the embrace the Ventolin can be administered, and anguish lessened for both parent and child.

\section{Being There}

The parent can hear the distress of a child through closed doors and through the curtains of sleep. What bonds there are here can never be just temporal. Whether nonhuman or human, we respond to the sonar call of distress as if the very words were screamed inside our sleeping brain.

A conversation of sounds melting constantly into rhythms.

A shell waiting for you to listen. (Rich, 1971, p. 53)

Who is the shell? The parent or the child? When we place an ear to the shell, when we are aware of a child's distress, do we also listen for the echo of ourselves? Is this experience of heightened awareness also the child inside us, remembering the need for presence and comfort, or just that in the nighttime quietness of our minds we are more open to each other? We are the ear and the shell: a paradox.

\section{Asthma as a Way of Being-in-the-World}

Asthma cannot be healed. However in writing our stories and searching for a thematic consciousness within them, Sasha and I have healed some "gashes in our understandings." Over the last few weeks we have mused, laughed, and sometimes cried at "our common fury of direction." The experience of asthma is Sasha's experience. Mine is the experience of loving a child living with asthma. The stories themselves are a reflection. We have learned from the stories, from the themes and from each other.

\section{References}

Cole, R.B. (1971). Essentials of respiratory disease. Toronto: Pitman. Heidegger, M. (1971). Poetry language thought. New York: Harper \& Row.

Heidegger, M. (1977). Basic writings. New York: Harper \& Row.

Kundera, M. (1984). The unbearable lightness of being. New York: Harper \& Row.

Livesay, D. (1986). The self-completing tree. Victoria, BC: Press Porcepic. 
Merleau-Ponty, M. (1962). Phenomenology of perception. London: Routledge \& Kegan Paul.

Rich, A. (1971). The will to change; poems 1968-1970. New York: Norton.

Rich A. (1981). A wild patience has taken me this far; poems 1978-1981. New York: Norton.

Rilke, R.M. (1964). Rilke: Selected poems. London: Penguin.

Sartre, J.-P. (1966). Being and nothingness. New York: Washington Square Press.

Whitman, W. (1891-1892). Leaves of grass. Mount Vernon, NY: Peter Pauper Press.

Van den Berg, J.H. (1972). A different existence. Pittsburgh, PA: Duquesne University Press. 